\title{
Perceptions of pre-retired employees of a public university about retirement
}

\author{
Percepções de trabalhadores pré-aposentados de uma instituição universitária pública \\ acerca da aposentadoria
}

Desirée Ariane Modos Figueira ${ }^{1}$, Maria do Carmo Lourenço Haddad ${ }^{1}$, Raquel Gvozd ${ }^{1}$

Objective: to unveil the perceptions of pre-retired employees of a public university about retirement. Methods: qualitative research conducted with 16 pre-retired employees of a public university. Data were collected in monthly meetings in three focus groups that discussed aspects related to retirement and were analyzed by content analysis technique. Results: when identifying retirement as a possibility, pre-retired workers rescued the meaning of work, reflected on the life changes that retirement can lead and signaled the need for strategies for experiencing retirement. Conclusion: retirement brings up positive and negative perceptions, concerns and questions that reinforce the need to offer to pre-retired workers the opportunity to reflect on this stage of life and prepare to enjoy the post-career period with quality.

Descriptors: Retirement; Work; Decision Making; Planning.

Objetivo: desvelar percepções de trabalhadores pré-aposentados de uma instituição universitária pública acerca da aposentadoria. Métodos: pesquisa qualitativa, desenvolvida com 16 pré-aposentados de uma instituição universitária pública. Dados coletados em encontros mensais, em três grupos de reflexão que discutiram aspectos relacionados à aposentadoria e analisados pela técnica de análise de conteúdo. Resultados: ao identificarem a aposentadoria como uma possibilidade, os pré-aposentados resgataram o significado do trabalho, refletiram sobre as mudanças de vida que a aposentadoria pode acarretar e sinalizaram a necessidade de estratégias para vivência da aposentadoria. Conclusão: a aposentadoria traz à tona percepções positivas e negativas, anseios e questionamentos que reforçam a necessidade de ofertar aos trabalhadores em pré-aposentadoria a oportunidade de refletir sobre esta fase da vida e se preparar para desfrutar da pós-carreira com qualidade. Descritores: Aposentadoria; Trabalho; Tomada de Decisões; Planejamento.

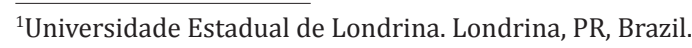




\section{Introduction}

Population aging has been a frequent subject of studies, bringing important reflections that have supported the formulation of policies that address the specific characteristics of this age group, as well as addressing the socio-economic challenges posed by this phenomenon, especially related to social security ${ }^{(1-2)}$.

Recent projections state that 1.2 billion people will be 60 years old or older by 2025, reaching 2 billion in 2050 , or about $22.0 \%$ of the population ${ }^{(1,3)}$. For Latin America, projections indicate percentage of $18.5 \%$ of elderly people by the year 2050 and, surprisingly, countries like Brazil, Chile and Mexico will have older populations than the United States. In Brazil, in the period from 1991 to 2011, the population aged 65 or more has doubled and has reached $12.1 \%$ of the total ${ }^{(3)}$.

In this sense, among the possible aspects to be investigated on aging and its coping with it, there is the subject of retirement, a milestone event in the worker's life. This is presumably the break with the systematic and compulsory labor, which is an important source of personal identity, construction of self-image, self-worth, the source of esteem and social integration $^{(4)}$.

Work is a social tool that provides the interrelationship with the world, and in the West, it has been central in the lives of individuals thanks to various historical and economic phenomena, of which the emergence of industrial society was certainly the most influential. From the intensification of industrialization, work has not only represented the way of producing consumer goods and services necessary for survival, or the means to earn a salary, but it has been also the basis for the construction of the identity of the human being ${ }^{(5-7)}$.

Thus, the end of an employment relationship brings the impact of coping with retirement when the individual experiences the closure of a routine established for years, the termination of relationships with colleagues, the absence of daily hours devoted to labor; starting to genuinely experience the free time for other activities, the extension of time for the marital and/or family relationship, and more contact with the domestic sphere ${ }^{(8)}$.

The social representation of retirement is linked to the construction made by individuals in different societies, as those who dignify older people tend to provide better conditions for adjusting to this new phase.

All experienced changes will require reconstruction in terms of self-image and socialization because, in theory, retirement should be the pinnacle of psychosocial well-being, the greatest reward for the years of work, a time to enjoy leisure and free time. However, for many workers, it is a troubled period of life, especially when considering that, in the eyes of the productive society, retirement is associated with physical and physiological depreciation from aging, as a period of decline, opposed by the social conception of appreciation of what is beautiful, strong, young and healthy ${ }^{(4,9)}$.

Thus, the conflict between retirement being a break or a continuity may represent the contradiction between the desire of the disengagement and the fear of getting lost, not recognizing oneself by failing to carry out the activities that had been making routinely in recent years. So, an unbearable feeling may arise, resulting from the rupture of identity generated by retirement $t^{(4)}$.

Therefore, pre-retirement seems to be a moment for reflection and planning on their own identity, expectations and priorities for the individual's future $^{(10)}$, as it is at this time of life that many workers face the greatest obstacles and indecisions that sometimes cause fear and uncertainty about the near future.

Given these considerations, the aim of this study was to unveil perceptions of pre-retired workers of a public university about retirement. 


\section{Methods}

It is a qualitative research, developed in a public university located in southern Brazil, which has approximately 5,061 employees, of which 3,404 work in administrative sector and 1,657 are teachers.

In this institution, a Preparation Program for Retirement was established in 2011, composed of two stages. The first stage includes a cycle of five lectures, which address the following topics: experiences and feelings in pre-retirement, social security legislation, domestic economy, citizenship and health aspects of pre-retirement. In the second stage, focus groups are formed, and this is a moment of closest approach between the participants, addressing several issues that promote discussions and reflections that can contribute to face the feelings that arise in the stage prior to retirement.

Research participants were pre-retirees who participated in the cycle of instructional lectures of the Preparation Program for Retirement in 2011, and who agreed to participate voluntarily in the focus groups about retirement that took place in 2012 .

At this stage, 20 pre-retirees signed up to participate, and three groups were formed. In the first group, eight pre-retirees participated; in the second, there were five participants; and in the third, seven. Four participants were excluded from the study because they attended only one meeting. Thus, the total population was 16 workers.

Five meetings were carried out between July and November 2012, with monthly frequency, and duration of approximately two hours each. These were coordinated by a teacher with experience in group dynamics and in research on the subject of retirement, who was also in the pre-retirement phase, and an observer who recorded the data from the discussions of each meeting in a field diary. No audio or video recording equipment was used for data collection because it is a vulnerable population to the discussed context, which could suppress the participation of pre-retirees in discussions.

Data analysis was done through the content analysis technique ${ }^{(11)}$. When transcribing the speeches, the letter P (for Participant) was used followed by the number corresponding to the pre-retiree and the group to which they belonged, in order to preserve the identity. From the analysis of the speeches, three categories emerged: Retirement as a possibility and the rescue of the meaning of work, Possible life changes brought about by retirement, Strategies for experiencing retirement.

The study complied with the formal requirements contained in the national and international regulatory standards of research involving human beings.

\section{Results}

Of the 16 participants, 14 were female and two were male. Of these, 13 worked in technical and administrative positions and three were teachers. The age of participants ranged from 49 to 68 years.

The discussions that permeated the five groups meetings allowed to identify participants had different feeling in facing retirement. It was found that it constitutes a difficult time of choices and decisions, because while some workers saw it as convenient circumstance, others saw it as a conflicting moment.

From the discussions of the focus groups about retirement, three categories emerged: Retirement as a possibility and the rescue of the meaning of work, Possible life changes brought about by retirement, Strategies for experiencing retirement.

\section{Retirement as a possibility and the rescue of the meaning of work}

The explanations pre-retirees revealed the diversity of feelings experienced by them when faced with the possibility of retirement, because for some workers this is a phase of doubts and uncertainty, 
while others see it as an opportunity to enjoy life. I decided I want to retire (P4, G2). I was surprised when I saw that I could already retire, there are times that I really want to stop, and there are times that I feel fear and think: and then what? (P1, G1). It allows us to enjoy the grandchildren, the family (P3, G2). I think it is time to enjoy life with health (P4, G2).

Given the perceived proximity of retirement, participants started to assimilate the meaning of work. For some, this is a source of pleasure and fulfillment; for others, it may represent an exhaustive and stressful routine. Here at the University I found a home, and I enjoy what I do. I can already retire, I think I'll wait to be expelled (P8, G1). I realized that during my vacation, I miss my job (P1, G1). I do not like what I do, so I do not hang on to my work. It is a routine work (P7, G1). I think work as a thesis, there comes a time that it is over; there is nothing to do anymore (P9, G3). I've worked enough, I gave my contribution. I face a lot of trouble at work (P3, G2). The competition that exists at work makes me suffer (P1, G1).

Work, as a lifetime structure, conditions the individual's activities, who must organize their daily lives according to the demands of the workload. This obligation was explained with displeasure by some participants because of the hardships resulting from work, which is a reason why some choose for retirement. The time spent at work, commuting, does not allow me to do other things I like; I end up giving up on pleasurable things (P10, G3). I cannot choose to travel now, if I wanted it, I would have pay hours for this to be possible, we lose in life things like these due to lack of time $(\mathrm{P} 4, \mathrm{G} 2)$.

Another aspect identified in the statements of participants refers to the fact that work is an important form of social interaction, which brings up some concerns about the possible loss of contact with the friends made in the workplace. I know I'll miss talking to my friends from work, my biggest concern with retirement is not having my co-workers to unload about issues that I only talk to them $(\mathrm{P} 4, \mathrm{G} 2)$.

At the same time, in this process, some participants allowed frustrations and grievances towards the institution to flourish as a way to facilitate decision-making for retirement. I am returning from a leave and it seems that everything changes, people take your space. Things will not fail to happen if you are not there. These things happen and make us sad (P1, G1).

Also in relation to the frustrations experienced in the work environment, a participant reported the current existing distancing between co-workers, weakening interpersonal relationships, which is a motivator for the decision for retirement. Today people are more in their own business, before we were closer (P5, G3).

Thus, it was found that the proximity of retirement leads pre-retirees to reflect on the opportunities arising from this new phase of life and the representation of work, which leads them to hesitate between the desire to retire or remain in the workplace.

\section{Possible life changes brought about by retirement}

After reflecting on the possibility of retiring and on the meaning of work in their lives, the participants showed concern about the need to face the changes brought about by retirement. One of the reported concerns referred to the loss of the server identity, verified in retirement. Many servers do not even want to call the retired colleagues to the end-of-year parties (P11, G1).

Another aspect that stood out in participants' reflections was the characteristic of unproductive assigned to retired people by society and the need to face aging and possible diseases. I am the same that entered here, I'm different. Today I woke up, did my makeup, I saw that my eyelid is fallen, I get desperate and talked to my husband that I was getting old (P7, G1). There is an obligation that society imposes about productivity and profitability (P15, G3).

At this time of proximity to retirement, it is clear to participants that they will have closer contact with their families, since the time before dedicated to the work will now be spent in the family environment. This is seen in different ways, for some, it is positive and whereas for others it is negative. I want to look for another home, make company for my husband who is now retired, for my daughter and for my mother (P12, G3). We have to be careful, if not family overload us. The family has to understand that (P13, G2). 
Another question that arises related to facing retirement is the need to follow modernity with new technologies in order to avoid being ignored by society. I am afraid of these times, I cannot keep it up, I think I'm getting so lost in time, I feel demented sometimes. I said demented because I cannot keep up with the computer, for example (P3, G2).

\section{Strategies for experiencing retirement}

When facing retirement, pre-retirees have realized the need to plan for that moment, which requires the incorporation of coping strategies. Planning helps to guide, I know that to retire I will have to plan, not to leave anything outstanding (P6, G3). I really want to retire, but I need to prepare myself $(\mathrm{P} 7, \mathrm{G} 1)$.

Participants attributed some perspectives for retirement, focused on the need to structure activities to better face this new stage of life. Therefore, there were accounts from pre-retirees that had already defined projects to be developed in retirement and others had not planned anything yet, but had identified this need. I have plans to set up a company with former students (P8, G1). I want to keep working in the academic area, maintaining a routine (P5, G3). I will not do anything, why do I need to do something? Not doing anything to me is not working in a job, but I will work at home, take care of the house (P14, G2). I want to do things until I get bored, like walking, taking care of my garden, doing little pajamas for babies, and when I get bored, I will stop and start another activity. When I get bored, I'll stop! (P1, G1). I plan to work with projects, teach courses, doing something in the organization area, I also like to work with the conservation of documents (P1, G1). I think to of having a farm, maybe a flower shop (P7, G1). I already have plans for retirement. I want to be church volunteer in one afternoon of the week, the other week I want to organize the library of a school that I had studied, I can help my husband to set up a company. My brother's wife had palsy in one side of the body, so I plan to stay an afternoon with her. I have several plans, and I am determined to stop working (P11, G1). I think of teaching after retirement, I started the master's degree thinking ahead (P13, G1).

\section{Discussion}

The poor adhesion of pre-retirees in preparing strategies for the retirement in the studied institution was a major limitation found in this study. The period before the break with the systematic and compulsory labor is a delicate moment of uncertainties and insecurities, which justify the delay of the subjects to adhere to this type of activity that bring out reflections on retirement.

The results showed that pre-retirees, when realizing the proximity of retirement, expressed feelings and perceptions that varied according to individual experiences and perspectives. At times retirement proved to be a chance to enjoy good times with family and friends, expand the moments of leisure and dedicate to self-care, and sometimes it was expressed through the fear of the unknown future of uncertainties and instabilities ${ }^{(12-13)}$.

The first contact of the group with the retirement issue was also the first approach of many with this reality, so the participants began to assimilate the possibility to stop working and rescued the meaning of work in their lives. Faced with new perceptions, the individual seeks reasons to base their decision on retirement. So, they start to reflect on issues involving their social and labor life linked to the meaning that work had throughout their lives, and organize ideas, rescuing the reasons that lead them to retirement or to continuing working ${ }^{(14-15)}$.

In this sense, work was highlighted by participants as a source of pleasure and fulfillment, or even as an exhaustive and tiring routine. Such perceptions can be associated with the historical significance of work, which went through a social evolution, thus taking many faces, and acquired distinct sides, such as generating and consuming life ${ }^{(16)}$. 
Participants expressed concern over the need to face the life changes resulting from retirement, as this means the break with the labor routine, the reach of freedom, but it also can indicate the onset of old age, the stigma of lack of productivity, the lack of daily activities that generate pleasure, the inactivity and the social exclusion ${ }^{(17-18)}$.

The issues highlighted cause in individuals a state of concern, placing them in a discomfortable position in this time of changes. One can also consider that such anxiety is a result of the conquest of control over the time before directed to work. Considering the need that man has to manage their own time, and the fact that they have lost that control with the historical evolution of the work, when faced with the new opportunity to regain control of life, they do not know how to act, and such changes may either promote growth and trigger psychological problems, which the worker is not prepared to experience ${ }^{(12-13,16)}$.

There is also the stigma that retired people are unproductive. This status is assigned by the capitalist society, mainly by the working class that moves the economy, which discourages pre-retirees who must face aging while facing this delicate period, in which they are labeled as unproductive, generators of socioeconomic loss. Still, there are the actual physiological factors arising from advancing age, which are characterized by health weakness associated or not with chronic diseases and consequent comorbidities, psychomotor and cognitive decline, progressive loss of functionality, characterized by the inability to perform activities independently ${ }^{(13,19)}$.

In this respect, in the course of the meetings, participants realized the need to define strategies to experience and adapt to retirement. Those workers who have well-defined post-career life projects enjoy a satisfactory retirement ${ }^{(4)}$.

The planning for retirement encompasses the establishment of social relationships outside the workplace; financial stability with investments and reserves, even to enjoy free time and leisure; projects of paid and volunteer work ${ }^{(4)}$. It should be noted that the labor experience is individual, and the preretirement is characterized as the period in which the worker can organize and plan what is to come, and decide the best time to stop ${ }^{(5)}$.

In this context, there is need for planning for retirement, through which the worker can enter this new phase subtly, adapting to the new, and thus can expand horizons, live new experiences, develop a schedule, keep active and member of society, establish perspectives of life and well-being and enjoy retirement with pleasure ${ }^{(5,20)}$.

Finally, it is highlighted two aspects for further reflection on this theme. First, the need to include in occupational health programs of companies projects of preparation for retirement, designed to prepare workers for the post-career period because when retirement is planned in advance, there are greater perspectives of success and satisfaction of this time of life. Second, the need to discuss in societies and with social partners the possibility of establishing an adjustment period after retirement, during which the retired person maintains a relationship to work, thus preparing for active aging and successive disengagement.

\section{Conclusion}

The participants, when realizing the proximity of retirement, rescued the meanings of work for the subjectivity of each individual, bringing up family values, the need for the pursuit of quality of life, which characterized the ambivalence of the desire to retire or the lack of it. Then, they reflected on life changes arising from the post-career period, as determinants of an uncertain future. Finally, they outlined strategies to face this cycle of life, as the establishment of new social relations and financial support.

Perceptions related to retirement were different, as these were directly related to labor experience built in their individuality. Thus, the 
subjectivity of experiences greatly affects the meanings and reflective strategies to face this new phase.

\section{Collaborations}

Figueira DAM and Haddad MCL contributed to the analysis and interpretation of data, article writing and approval of the final version. Gvozd R contributed to the project design, analysis and interpretation of data, article writing and approval of the final version.

\section{References}

1. World Health Organization. Towards policy for health and ageing [Internet]. 2016 [cited 2016 Apr 30]. Available from: http://www.who.int/ ageing/publications/alc_fs_ageing_policy.pdf

2. Center for Strategic and International Studies. Latin America's Aging Challenge [Internet]. 2009 [cited 2016 Apr 30]. Available from: http://csis. org/files/media/csis/pubs/090324_gai_english. pdf

3. Presidência da República (BR). Secretaria de DireitosHumanos.SecretariaNacionaldePromoção Defesa dos Direitos Humanos. Dados sobre o envelhecimento no Brasil [Internet]. 2016 [citado 2016 abr 30]. Disponível em: http://www.sdh.gov. br/assuntos/pessoa-idosa/dados-estatisticos/ DadossobreoenvelhecimentonoBrasil.pdf

4. Selig GA, Valore LA. Imagens da aposentadoria no discurso de pré-aposentados: subsídios para a orientação profissional. Cad Psicol Soc Trab. 2010; 13(1):73-87.

5. Araújo LP. Aposentadoria como proposta de qualificação para uma vida saudável. Rev Incelências. 2011; 2(2):63-77.

6. Bendassolli PF. Críticaàs apropriações psicológicas do trabalho. Psicol Soc. 2011; 23(1):75-84.
7. Zanelli JC, Silva N, Soares DH. Orientação para aposentadoria nas organizações de trabalho: construção de projetos para o pós-carreira. Rev Psicol Org Trab [Internet]. 2010 [citado 2015 ago 20]; 10(2):177-81. Disponível em: https:// periodicos.ufsc.br/index.php/rpot/article/ view/22217/20156

8. Moura GA, Souza LK. Autoimagem, socialização, tempo livre e lazer: quatro desafios à velhice. Textos Contextos. 2012; 11(1):172-83.

9. Oliveira JC. O dia seguinte da aposentadoria: sonhos e realidade. In: Barros Júnior JC, organizador. Empreendedorismo, trabalho e qualidade de vida na terceira idade. São Paulo: Edicon; 2009. p.283-93.

10. Barbosa TM, Traesel ES. Pré-aposentadoria: um desafio a ser enfrentado. Barbaroi [Internet]. 2013 [citado 2015 ago 29]; 38:215-34. Disponível em:http://pepsic.bvsalud.org/pdf/barbaroi/ n38/n38a12.pdf

11. Bardin L. Análise de conteúdo. Lisboa: Edições 70; 2010.

12. Bressan MALC, Mafra SCT, França LHFP, Melo MSS, Loretto MDS. Bem-estar na aposentadoria: o que isto significa para os servidores públicos federais. Rev Bras Geriatr Gerontol. 2013; 16(2):259-72.

13. Debetir E. Aposentadoria oportunidade de realizar projetos e/ou momento de crise? Rev Carreiras Pessoas. 2011; 1(2):43-67.

14. França LHFP, Menezes GS, Bendassolli PF, Macedo LSS. Aposentar-se ou continuar trabalhando? O que influencia essa decisão? Psicol Ciênc Prof. 2013; 33(3):548-63.

15. Meneses RMV, Silva RTS, Carvalho RFD, Santos APDOBS, Almeida JAVD, Medeiros ATND. Educational actions for the elderly. Rev Rene. 2013; 14(2):417-27.

16. Martins JCOM, Aquino CAB, Sabóia IBS, Pinheiro AG. De Kairós a Kronos: metamorfoses do trabalho na linha do tempo. Cad Psicol Soc Trab [Internet]. 2012 [citado 2015 ago 29]; 15(2):21928. Disponível em: http://pepsic.bvsalud.org/ pdf/cpst/v15n2/v15n2a05.pdf. 
17. Panozzo EAL, Monteiro JK. Aposentadoria e saúde mental: uma revisão de literatura. Cad Psicol Soc Trab [Internet]. 2013 [citado 2015 ago 29]; 16(2):199-209. Disponível em: http://pepsic. bvsalud.org/pdf/cpst/v16n2/a05v16n2.pdf.

18. Rebouças M, Matos RM, Ramos LR, Cecílio LCO. 0 que há de novo em ser velho. Saúde Soc. 2013; 22(4):1226-35.
19. Santos VB, Tura LFR, Arruda AMS. As representações sociais de "pessoa velha" construída por idosos. Saúde Soc. 2013; 22(1):138-47.

20. França LHFP, Menezes GS, Siqueira AR. Planejamento para aposentadoria: a visão dos garis. Rev Bras Geriatr Gerontol. 2012; 15(4):73345. 